\title{
LEARNING RESPONDING \\ TO THE RELIGIOUS VALUES OF POETRY "KETIKA ENGKAU BERSEMBAHYANG" BY EMHA AINUN NADJIB
}

\author{
Solih Hartati \\ Universitas Suryakancana Cianjur \\ email: solihhartati74@yahoo.com
}

\begin{abstract}
This article is intended to describe the learning respond religious value in poetry. The purpose of this study is to determine how test results and student feedback regarding religious values contained in Poetry When you pray Emha Ainun Nadjib work. This research uses descriptive method. The research objectives are students of class X-2 SMA PGRI Cianjur. Data collection techniques were used that technique tests and questionnaires. Based on the research that has been conducted on Learning Responding Value of Religious in Poetry "When you pray," Works emha ainun nadjib most students or nearly all students get good grades, and most or nearly all students provide feedback-In answer is good about values religious contained in poetry related to the value relgius faith, istiqomahan, sense of patience, gratitude, compassion, and courageous do not despair. Meanwhile, based on a questionnaire given to students of all students enjoy participating in learning the Indonesian language, and Values contained in the poem when you pray.
\end{abstract}

Keywords: poetry, religious values.

\section{PENDAHULUAN}

Sastra merupakan bagian dari kebudayaan. Dalam mengkaji kebudayaan, tidak dapat melihatnya sebagai sesuatu yang statis, yang tidak berubah, tetapi merupakan sesuatu yang dinamis, yang senantiasa berubah (Semi, 2013:54). Karya sastra pada umumnya sudah diajarkan di sekolah sejak dini, pembelajaran karya sastra bertujuan untuk mencapai suatu tujuan pembelajaran tertentu.

Karya sastra merupakan hasil pemikiran atau imajinasi seseorang yaitu seorang pengarang yang diekspresikan baik secara lisan maupun tulisan. Ekspresi tersebut merupakan hasil ide, perasaan, dan keyakinan seseorang yang dituangkan dalam karya sastra melalui media bahasa. Bahasa dalam karya sastra memiliki nilai estetika dan kaya akan makna. Oleh sebab itu, sastra memiliki banyak kelebihan karena sastra memiliki bahasa yang khas dan unik. Untuk memahami sebuah karya sastra diperlukan pemahaman yang mendalam atau pemahaman yang luas mengenai sastra. Karya sastra yang bermutu yaitu karya sastra yang di dalamnya mengandung nilai-nilai atau pesan yang akan disampaikan pengarang pada pembaca.

Dalam karya sastra terdapat tiga genre sastra salah satunya yaitu puisi. Puisi sebagai salah satu karya seni sastra dapat dikaji dari bermacam-macam aspek. Menurut Gani (2014:15) puisi termasuk salah satu genre sastra yang berisi ungkapan perasaan penyair yang mengandung rima dan irama, serta diungkapkan dengan pilihan kata yang cermat dan tepat. karya sastra yang bermutu yaitu karya sastra yang mengandung nilai-nilai atau pesan-pesan yang akan disampaikan pengarang pada pembaca. Nilai-nilai dalam karya sastra tersebut salah satunya yaitu nilai religius. Nilai religius (ketuhanan) yang bersifat mutlak dan bersumber pada keyakinan manusia (Herimanto, 2014:129). Oleh karena itu, di tengah krisis moral yang melanda bangsa Indonesia dilakukan penelitian yang berkaitan dengan nilai-nilai 
religius, agar masyarakat dan khususnya siswa di sekolah mendapatkan pencerahan dan lebih jauh menjadi tidak menyimpang dari ajaran-ajaran agama.

Penelitian dilakukan karena rendahnya pemahaman siswa dalam pembelajaran menanggapi nilai relgius, serta belum maksimalnya pembelajaran menanggapi nilai religius sehingga pelaksanaan pembelajaran menanggapi nilai-nilai religius pada puisi belum memuaskan.

Dengan penelitian yang dilakukan, diharapkan mampu meningkatkan pemahaman siswa terhadap nilai-nilai religius yang terkandung dalam puisi karya Emha Ainun Nadjib. Karena rendahnya pemahaman siswa terhadap nilai-nilai religius yang terkandung dalam puisi tersebut. Pada umumnya nilai religius sangat erat kaitannya dengan kehidupan sehari-hari. Penelitian dimaksudkan untuk memperbaiki tingkah laku atau perilaku siswa dalam kehidupan sehari-hari, agar tidak menyimpang dari ajaran agama.

\section{METODE}

Penelitian dilaksanakan secara deskriptif. Subjek dalam penelitian adalah siswa kelas X-2 SMA PGRI Cianjur yang berjumlah 36 orang (16 laki-laki, dan 20 perempuan). Penelitian ini di laksanakan pada tanggal 11 April sampai 17 April 2016.

Data dikumpulkan dengan instrumen penelitian sebagi berikut. (1) lembar tugas siswa, lembar soal siswa ini berupa pertanyaan yang dikhususkan untuk siswa. Lembar kerja siswa ini bertujuan untuk mengumpulkan data mengenai kemampuan siswa dalam pembelajaran menanggapi nilai religius dalam puisi Ketika Engkau Bersembahyang. (2) angket, Seperti yang telah dijelaskan pada teknik penelitian bahwa angket yang digunakan pada penelitian adalah jenis angket tertutup. Lembar angket ini berupa sejumlah pertanyaan yang berupa pilihan ganda berjumlah 10 butir pertanyaan dengan masing-masing soal mengandung 2 butir alternatif jawaban. Tetapi, sebelum merumuskan pertanyaan dibuat terlebih dahulu kisi-kisi untuk angket tersebut. Hal ini dimaksudkan untuk memperjelas setiap masalah yang ingin ditanyakan kepada siswa. Kemudian, setelah data terkumpul lalu data di analisis sesuai dengan hasil yang diperoleh.

\section{HASIL DAN PEMBAHASAN}

\section{Hasil}

Data hasil tes dalam menanggapi nilai religius yang berbuhungan dengan rasa kasih sayang, keimanan, keistiqomahan, bersyukur, sabar, dan teguh hati tidak berputus asa dapat diketahui bahwa hasil tanggapan siswa sebanyak 10 orang mendapatkan nilai 90 , yang berada pada interval persentase (8694\%). Selanjutnya, berdasarkan analisis data hasil tes pada siswa mengenai menanggapi nilai religius yang berhubungan dengan rasa kasih sayang, keimanan, keistiqomahan, bersyukur, sabar, dan teguh hati tidak putus asa diketahui bahwa hasil tanggapan siswa sebanyak 22 orang mendapatkan nilai 80, yang berada pada interval persentase (76$85 \%)$.

Berdasarkan data tersebut, mengenai hasil analisis tes pada siswa tentang menanggapi nilai religius yang berbuhungan dengan rasa kasih sayang, keimanan, keistiqomahan, bersyukur, sabar, dan teguh hati tidak putus asa dapat diketahui bahwa berdasarkan tanggapan siswa sebanyak 4 orang siswa memperoleh nilai 70, yang berada pada interval persentase (66-75\%). Berdasarkan data di atas dapat diketahui tanggapan siswa mengenai nilai religius yang terkandung dalam puisi Ketika Engkau Bersembahyang tanggapan siswa mengenai nilai religius tersebut sebagai berikut.

Berhubungan dengan keimanan, 10 orang siswa memberikan tanggapan yang baik sekali mengenai nilai religius yang berhubungan dengan keimanan, kemudian 22 orang siswa memberikan tanggapan yang baik mengenai nilai religius yang 
berhubungan dengan keimanan, dan siswa sebanyak 4 orang memberikan tanggapan yang cukup baik mengenai nilai religius yang berhubungan dengan keimanan. Berdasarkan data tersebut, sebagian besar siswa atau hampir seluruhnya siswa memberikan tanggapan yang baik mengenai nilai religius yang berhubungan dengan keimanan.

Berdasarkan data yang diperoleh, tanggapan siswa yang berhubungan dengan rasa kasih sayang, sebanyak 10 orang memberikan tanggapan yang sangat baik mengenai nilai religius yang berhubungan dengan rasa kasih sayang, sedangkan siswa sebanyak 22 orang memberikan tanggapan yang baik mengenai nilai religius yang berhubungan dengan rasa kasih sayang, dan 4 orang siswa memberikan tanggapan yang cukup baik mengenai nilai religius yang berhubungan dengan rasa kasih sayang. Berdasarkan tanggapan tersebut, dapat diketahui bahwa sebagian besar atau hampir seluruhnya siswa memberikan tanggapan yang baik mengenai nilai religius yang berhubungan dengan rasa kasih sayang.

Berdasarkan data tersebut tanggapan siswa yang berhubungan dengan keistiqomahan, siswa sebanyak 10 orang memberikan tanggapan yang sangat baik mengenai nilai religius yang berhubungan dengan keistiqomahan, kemudian siswa sebanyak 22 orang memberikan tanggapan yang baik mengenai nilai religius yang berhubungan dengan keistiqomahan, dan siswa sebanyak 4 orang memberikan tanggapan yang cukup baik mengenai nilai religius yang berhubungan dengan nilai religius keistiqomahan. Berdasarkan data tersebut, sebagian besar siswa atau hampir seluruhnya siswa memberikan tanggapan yang baik mengenai nilai religius yang berhubungan dengan keistiqomahan.

Berdasarkan data tersebut, tanggapan siswa yang berhubungan dengan rasa sabar, siswa sebanyak 10 orang memberikan tanggapan yang sangat baik mengenai nilai religius yang berhubungan dengan rasa sabar, kemudian siswa sebanyak 22 orang memberikan tanggapan yang baik mengenai nilai religius yang berhubungan dengan rasa sabar, dan siswa sebanyak 4 orang memberikan tanggapan yang cukup baik mengenai nilai religius yang berhubungan dengan rasa sabar. Berdasarkan data tersebut, sebagian besar siswa atau hampir seluruhnya siswa memberikan tanggapan yang baik mengenai nilai religius yang berhubungan dengan rasa sabar.

Berdasarkan data tersebut juga, dapat diketahu tanggapan siswa berhubungan dengan rasa bersyukur, siswa sebanyak 10 orang memberikan tanggapan yang sangat baik mengenai nilai religius yang berhubungan dengan rasa bersyukur, kemudian siswa sebanyak 22 orang memberikan tanggapan yang baik mengenai nilai religius yang berhubungan dengan rasa bersyukur, dan siswa sebanyak 4 orang memberikan tanggapan yang cukup baik mengenai nilai religius yang berhubungan dengan rasa bersyukur.

Dengan demikian, sebagian besar siswa atau hampir seluruhnya siswa memberikan tanggapan yang baik mengenai nilai religius yang berhubungan dengan rasa bersyukur, dan selanjutnya, berdasarkan data berhubungan dengan rasa teguh hati dan tidak berputus asa, siswa sebanyak 10 orang memberikan tanggapan yang sangat baik mengenai nilai religius yang berhubungan dengan rasa teguh hati dan tidak berputus asa, kemudian siswa sebanyak 22 orang memberikan tanggapan yang baik mengenai nilai religius yang berhubungan dengan rasa teguh hati tidak berputus asa, dan siswa sebanyak 4 orang memberikan tanggapan yang cukup baik mengenai nilai religius yang berhubungan dengan rasa teguh hati dan tidak putus asa.

Kemudian, diketahui sebagian besar siswa atau hampir seluruhnya siswa memberikan tanggapan yang baik mengenai nilai religius yang berhubungan dengan rasa teguh hati dan tidak putus asa. Berdasarkan data 
hasil analisis data angket dapat diketahui deskripsi data hasil angket yaitu, Pada pertanyaan nomor satu yaitu ketertarika siswa dalam pembelajaran sastra, sebanyak 32 orang siswa menjawab "Ya" yang berada pada interval persentase $(89 \%)$ dan 4 orang siswa menjawab "Tidak" berada pada interval persentase $(11 \%)$, sedangkan, pada pertanyaan nomor dua yaitu ketertatikan siswa terhadap puisi Ketika Engkau Bersembahyang, berdasarkan data tersebut sebanyak 36 orang siswa menjawa "Ya" yang berada pada interval persentase $(100 \%)$.

Selanjutnya, pada pertanyaan nomor tiga yaitu ketertarikan siswa dalam pembelajaran bahasa Indonesia, siswa sebanyak 36 orang menjawab "Ya" yang berada pada interval persentase (100\%). Kemudian, berdasarkan data tersebut pada pertanyaan nomor empat yaitu, pentingnya nilai-nilai yang terkandung dalam karya sastra, sebanyak 36 orang siswa menjawab "Ya" yang berada pada interval persentase (100\%). Serta berdasarkan data tersebut, pada pertanyaan nomor lima yaitu mengenai materi pembelajaran menganalisi nilai religius pada puisi Ketika Engkau Bersembahyang, sebanyak 20 orang siswa menjawab "Ya" yang berada pada interval persentase $(55,5 \%)$ dan sebanyak 16 orang menjawab "Tidak" yang berada pada interval persentase $(44,5 \%)$.

Berdasarkan data tersebut, dapat diketahui pada pertanyaan nomor enam yaitu, mengenai pentingnya nilai-nilai yang terkandung dalam karya sastra terutama nilai religius, sebanyak 36 orang siswa menjawab "Ya" yang berada pada interval persentase (100\%). Berdasarkan data tersebut, dapat diketahu pada pertanyaan nomor tujuh yaitu mengenai hambatan siswa dalam memahami karya sastra, sebanyak 9 orang menjawab "Ya' yang berada pada interval persentase (25\%) dan 27 orang menjawab "Tidak" yang berada pada interval persentase (75\%). Kemudian, berdasarkan data tersebut dapat diketahui pada pertanyaan nomor delapan yaitu mengenai kelayakan puisi Ketika Engkau Bersembahyang untuk dijadikan bahan pembelajaran, berdasarkan data tersebut siswa sebanyak 36 orang menjawab "Ya", yang berada pada interval persentase $(100 \%)$. Sedangkan, berdasarkan data tersebut juga dapat diketahu pada pertanyaan nomor sembilan yang berhubungan dengan penggunaan bahasa dalam puisi Ketika Engkau Bersembahyang, siswa sebanyak 20 orang menjawab "Ya", yang berada pada interval persentase $(55,5 \%)$ dan 16 orang siswa menjawab "Tidak" yang berada pada interval persentase $(44,5 \%)$, dan pada pertanyaan nomor sepuluh yang berhubungan dengan penggunaan bahasa dalam puisi Ketika Engkau Bersembahyang, berdasarkan data tersebut, siswa sebanyak 21 orang menjawab "Ya" yang berada pada interval persentase $(58,4 \%)$ dan 15 orang siswa menjawab "Tidak" yang berada pada interval persentase $(41,6 \%)$.

\section{Pembahsan}

Berdasarkan analisis data hasil tes pada siswa mengenai menanggapi nilai religius yang berbuhungan dengan rasa kasih sayang, keimanan, keistiqomahan, bersyukur, sabar, dan teguh hati tidak berputus asa dapat diketahui hasil dari tanggapan siswa, bahwa siswa sebanyak 10 orang mendapatkan nilai 90 , yang berada pada interval persentase (8694\%) siswa tersebut masuk ke dalam kategori "Baik sekali." Berdasarkan data tersebut, 22 orang siswa memiliki kemampuan yang baik sekali dalam pembelajaran menanggapi nilai religius yang terdapat dalam puisi, serta memberikan tanggapan yang sangat baik mengenai nilai-nilai religius yang tekandung dalam puisi tersebut.

Kemudian, berdasarkan analisis data tersebut dapat diketahui hasil tes pada siswa mengenai menanggapi nilai religius yang berbuhungan dengan rasa kasih sayang, keiman, keistiqomahan, bersyukur, sabar, dan teguh hati tidak berputus asa dapat diketahui hasil dari tanggapan siswa, bahwa siswa sebanyak 22 orang mendapatkan nilai 80, yang berada pada interval persentase (76$85 \%$ ) siswa tersebut masuk kedalam kategori 
"Baik." Dilihat dari hasil skala persentase 22 orang siswa sudah baik dalam pembelajaran menanggapi nilai religius atau kemampuan siswa dalam pembelajaran menanggapi nilai religius sudah dapat dikatakan baik, serta memberikan tanggapan yang baik mengenai nilai-nilai religius yang terkandung dalam puisi tersebut.

Berdasarkan data hasil analisis tes pada siswa tentang menanggapi nilai religius yang berhubungan dengan rasa kasih sayang, keimanan, keistiqomahan, bersyukur, sabar, dan teguh hati tidak putus asa dapat diketahui hasil dari tanggapan siswa, bahwa siswa sebanyak 4 memperoleh nilai 70, yang berada pada interval persentase (66-75 \%) siswa tersebut masuk ke dalam kategori "Cukup." Dilihat dari hasil skala persentase siswa tersebut, dapat diketahui kemampuan siswa dalam pembelajaran menanggapi nilai religius pada puisi cukup memahami, serta memberikan tanggapan yang cukup baik mengenai nilai-nilai religius yang terkandung dalam puisi tersebut.

Berdasarkan data-data tersebut dapat diketauih bahwa sebagian besar siswa atau hampir seluruhnya siswa sudah dikatakan baik dalam menanggapi nilai-nilai religius yang terdapat dalam sebuah puisi, serta kemampuan siswa dalam menanggapi nilainilai religius yang terkandung dalam puisi sudah baik, dan memberikan tanggapantanggapan yang baik. Kemudian, Berdasarkan data tersebut dapat diketahui tanggapan siswa mengenai nilai religius yang terkandung dalam puisi Ketika Engkau Bersembahyang. Tanggapan siswa mengenai nilai religius yang berhubungan dengan keimanan, 10 orang siswa memberikan tanggapan yang baik sekali mengenai nilai religius yang berhubungan dengan keimanan, kemudian 22 orang siswa memberikan tanggapan yang baik mengenai nilai religius yang berhubungan dengan keimanan, dan siswa sebanyak 4 orang memberikan tanggapan yang cukup baik mengenai nilai religius yang berhubungan dengan keimanan.
Berdasarkan data tersebut sebagian besar siswa atau hampir seluruhnya siswa memberikan tanggapan yang baik mengenai nilai religius yang berhubungan dengan keimanan. Karena, sebagai umat muslim kita harus senantiasa beriman kepada Allah SWT, keimanan merupakan salah satu tiang untuk kehidupan kita sendiri agar kita tidak lepas dari ajaran-ajaran agama yang kita anut. Kemudian, berdasarkan data tersebut berhubungan dengan rasa kasih sayang, siswa sebanyak 10 orang memberikan tanggapan yang sangat baik mengenai nilai religius yang berhubungan dengan rasa kasih sayang.

Sebanyak 22 orang memberikan tanggapan yang baik mengenai nilai religius yang berhubungan dengan rasa kasih sayang, dan 4 orang siswa memberikan tanggapan yang cukup baik mengenai nilai religius yang berhubungan dengan rasa kasih sayang. Berdasarkan tanggapan tersebut, dapat diketahui bahwa sebagian besar atau hampir seluruhnya siswa memberikan tanggapan yang baik mengenai nilai religius yang berhubungan dengan rasa kasih sayang. Sebagai umat yang beragama kita harus saling menyayangi antar sesama, baik sesama pemeluk agama Islam maupun dengan pemeluk agama lain.

Berdasarkan data tersebut, tanggapan siswa yang berhubungan dengan keistiqomahan, siswa sebanyak 10 orang memberikan tanggapan yang sangat baik mengenai nilai religius yang berhubungan dengan keistiqomahan, kemudian siswa sebanyak 22 orang memberikan tanggapan yang baik mengenai nilai religius yang berhubungan dengan keistiqomahan, dan siswa sebanyak 4 orang memberikan tanggapan yang cukup baik mengenai nilai religius yang berhubungan dengan nilai religius keistiqomahan.

Berdasarkan data tersebut, sebagian besar siswa atau hampir seluruhnya siswa memberikan tanggapan yang baik mengenai nilai religius yang berhubungan dengan keistiqomahan. Sebagai umat yang beragama kita harus senantiasa beristiqomah atau yakin 
terhadap agama yang kita anut, sehingga kita tidak mudah terpengaruh oleh ajaran agama lainnya.

Berdasarkan data tersebut, tanggapan siswa mengenai nilai religius yang berhubungan dengan rasa sabar. Siswa sebanyak 10 orang memberikan tanggapan yang sangat baik mengenai nilai religius yang berhubungan dengan rasa sabar, serta siswa sebanyak 22 orang memberikan tanggapan yang baik mengenai nilai religius yang berhubungan dengan rasa sabar, dan siswa sebanyak 4 orang memberikan tanggapan yang cukup baik mengenai nilai religius yang berhubungan dengan rasa sabar.

Berdasarkan data tersebut sebagian besar siswa atau hampir seluruhnya siswa memberikan tanggapan yang baik mengenai nilai religius yang berhubungan dengan rasa sabar. Kita harus senantiasa memiliki rasa sabar yang tiada batasnya. Karena, sebagai umat beragama kita harus selalu sabar dalam menjalani kehidupan dan juga harus selalu sabar dalam menjalani segala cobaan yang Allah SWT berikan kepada kita, dan berdasarkan data tersebut tanggapan siswa mengenai nilai religius yang berhubungan dengan rasa bersyukur, siswa sebanyak 10 orang memberikan tanggapan yang sangat baik mengenai nilai religius yang berhubungan dengan rasa bersyukur. Kemudian, siswa sebanyak 22 orang memberikan tanggapan yang baik mengenai nilai religius yang berhubungan dengan rasa bersyukur, dan siswa sebanyak 4 orang memberikan tanggapan yang cukup baik mengenai nilai religius yang berhubungan dengan rasa bersyukur.

Berdasarkan data tersebut sebagian besar siswa atau hampir seluruhnya siswa memberikan tanggapan yang baik mengenai nilai religius yang berhubungan dengan rasa bersyukur. Kita harus selalu bersyukur dengan nikmat Allah yang telah diberikan kepada kita, serta kita harus selalu mensyukuri apapun yang kita miliki, dan berdasarkan data tersebut, tanggapan siswa mengenai nilai religius yang berhubungan dengan rasa teguh hati dan tidak berputus asa. Siswa sebanyak 10 orang memberikan tanggapan yang sangat baik mengenai nilai religius yang berhubungan dengan rasa teguh hati dan tidak berputus asa. Kemudian, siswa sebanyak 22 orang memberikan tanggapan yang baik mengenai nilai religius yang berhubungan dengan rasa teguh hati tidak berputus asa, dan siswa sebanyak 4 orang memberikan tanggapan yang cukup baik mengenai nilai religius yang berhubungan dengan rasa teguh hati dan tidak putus asa.

Berdasarkan data tersebut sebagian besar siswa atau hampir seluruhnya siswa memberikan tanggapan yang baik mengenai nilai religius yang berhubungan dengan rasa teguh hati dan tidak putus asa. Dalam hidup kita harus selalu teguh hati dalam mengambil keputusan, serta tidak mudah putus asa apabila kita diberikan cobaan oleh Allah SWT. Karena, Allah SWT tidak akan memberikan cobaan di atas kemampuan umatnya.

Berdasarkan analisis data hasil tes siswa, mengenai menanggapi nilai religius yang berhubungan dengan rasa kasih sayang, keiman, keistiqomahan, bersyukur, sabar, dan teguh hati tidak putus asa dapat diketahui bahwa hasil dari tanggapan siswa, siswa yang mendapatkan nilai 90 sebanyak 10 orang, siswa yang mendapatkan nilai 80 sebanyak 22 orang, dan siswa yang mendapatkan nilai 70 sebanyak 4 orang.

Berdasarkan data hasil tes pada siswa dapat dinyatakan bahwa sebagain besar atau hampir seluruhnya kemampuan siswa sudah dinyatakan baik dalam pembelajaran menanggapi nilai-nilai religius yang berhubungan dengan rasa kasih sayang, keimanan, keistiqomahan, bersyukur, sabar, dan teguh hati tidak putus asayang terkandung dalam puisi Ketika Engkau Bersembahyang karya Emha Ainun Nadjib atau tanggapan siswa mengenai nilai-nilai religius yang berhubungan dengan rasa kasih sayang, sabara, keistiqomahan, bersyukur, teguh hati tidak 
putus asa, dan mengenai keimanan sebagaian besar siswa atau hampir seluruhnya siswa memberikan tanggapan yang baik mengenai nilai-nilai religus tersebut. Sehingga, dapat diketahui bahwa siswa sudah mampu menanggapi nilai-nilai religius dalam puisi tersebut, serta memberikan tanggapantanggapan yang baik. Berdasarkan deskripsi data hasil analisis angket disajikan pembahasan mengenai hasil angket yaitu, berdasarkan data tersebut, pada pertanyaan nomor satu siswa sebanyak 32 orang menjawab "Ya" yang berada pada interval persentase $(89 \%)$ dinyatakan "Hampir seluruhnya", hampir seluruhnya siswa memberikan tanggapan bahwa mereka sangat menyukai pembelajaran sastra khususnya pembelajaran puisi. Hal ini berarti siswa sangat memiliki antusias untuk mengikuti pembelajaran puisi, adapun 4 orang siswa menjawab "Tidak" yang berada pada interval persentase (11\%) dinyatakan "Sebagian kecil", sebagian kecil siswa tidak menyukai pembelajaran sastra khususnya puisi atau dapat dikatakan sangat tidak antusias dalam pembelajaran sastra terutama puisi.

Sedangkan, berdasarkan data tersebut pada pertanyaan nomor dua sebanyak 36 orang siswa menjawab "Ya" yang berada pada interval persentase $(100 \%)$ dinyatakan "Seluruhnya", seluruh siswa sangat menyukai puisi Ketika Engkau Bersembahyang atau siswa sangat senang ketika pembelajaran puisi tersebut. Selanjutnya, berdasarkan data tersebut pada pertanyaan nomor tiga siswa sebanyak 36 menjawab "Ya" yang berada pada interval persentase $(100 \%)$ dinyatakan "Seluruhnya", seluruh siswa sangat menyukai atau senang mengikuti pembelajaran bahasa Indonesia. Hal ini berarti siswa memiliki antusias yang tinggi untuk mengikuti pembelajaran bahasa Indonesia. Karena, seluruh siswa sangat menyukai pembelajaran bahasa Indonesia. Kemudian, berdasarakan data tersebut pada pertanyaan nomor empat, siswa sebanyak 36 menjawab "Ya" yang berada pada interval persentase (100\%) dinyatakan "Seluruhnya", seluruh siswa memberikan tanggapan bahwa nilai-nilai religius dalam puisi Ketika Engkau Bersembahyang banyak menyumbang nilainilai yang bermanfaat dalam kehidupan sehari-hari. Sehingga, siswa senang mempelajarinya.

Berdasarka data tersebut, pada pertanyaan nomor lima, siswa sebanyak 20 orang menjawab "Ya" yang berada pada interval persentase $(55,5 \%)$ dinyatakan "Sebagian besar", sebagaian besar siswa sudah pernah mempelajari nilai-nilai religius yang terkandung dalam puisi Ketika Engkau Bersembahyang. Sedangkan, siswa sebanyak 16 orang menjawab "Tidak" yang berada pada interval persentase $(44,5 \%)$ dinyatakan "Hampir setengahnya", hampir setengahnya siswa menyatakan belum pernah mempelajari nilai-nila religius yang terkandung dalam puisi Ketika Engkau Bersembahyang. Senada dengan itu, berdasarkan data tersebut pada pertanyaan nomor enam, siswa sebanyak 36 menjawab "Ya" yang berada pada interval persentase $(100 \%)$ dinyatakan "Seluruhnya", seluruh siswa menyatakan bahwa nilai-nilai religius sangat penting untuk dipelajari, karena krisis moral yang terjadi di negara kita, serta siswa menganggap bahwa nilainilai religius sangat penting untuk dipelajari.

Berdasarkan data tersebut, pada pertanyaan nomor tujuh siswa sebanyak 9 orang menjawab "Ya" yang berada pada interval persentase $(25 \%)$ dinyatakan "Sebagian kecil", sebagian kecil siswa mengalami kesulitan dalam pembelajaran menanggapi nilai religius pada puisi. Sedangkan, siswa sebanyak 27 orang $(75 \%)$ dinyatakan "Sebagian besar", sebagian besar siswa tidak mengalami hambatan dalam pembelajaran menanggapi nilai religius pada puisi tersebut. Pada pertanyaan nomor delapan, siswa sebanyak 36 orang menjawab "Ya" yang berada pada interval persentase (100\%) dinyatakan "Seluruhnya", seluruh siswa menyatakan bahwa puisi tersebut layak untuk dijadikan sebagai bahan pembelajaran sastra di SMA. 
Kemudian, berdasarkan data tersebut pada pertanyaan nomor sembilan, siswa sebanyak 20 orang menjawab "Ya" yang berada pada interval persentase $(55,5 \%)$ dinyatakan "Sebagian besar", sebagian besar siswa mengatakan bahwa bahasa yang digunakan dalam puisi tersebut dapat di pahami dengan mudah. Sedangkan, siswa sebanyak 16 orang menjawab "Tidak" yang berada pada interval persentase $(44,5 \%)$ dinyatakan "Hampir setengahnya", hampir setengahnya siswa menyatakan bahwa bahasa yang digunakan dalam puisi tersebut tidak mudah dipahami, dan berdasarkan data tersebut, pada pertanyaan nomor sepuluh, siswa sebanyak 21 orang menjawab "Ya" yang berada pada interval $(58,4 \%)$ dinyatakan sebagian besar, sebagaian besar siswa menyatakan sudah pernah membaca puisi Ketika Engkau Bersembahyang karya Emha Ainun Nadjib. Kemudian, siswa sebanyak 15 orang menjawab "Tidak" yang berada pada interval persentase $(41,6 \%)$ dinyatakan "Hampir setengahnya", hampir setengahnya siswa belum pernah membaca puisi Ketika Engkau Bersembahyang karya Emha Ainun Nadjib.

Berdasarkan data-data di atas siswa sangat antusias atau sangat menyukai pembelajran bahasa Indonesia terutama pembelajran sastra khususnya puisi, bahkan hampir seluruhnya siswa memberikan tanggapan bahwa mereka sangat menyukai pembelajaran sastra khususnya pembelajaran puisi. Hal ini berarti siswa sangat memiliki antusias yang tinggi untuk mengikuti pembelajaran puisi. Bahkan seluruh siswa sangat menyukai puisi Ketika Engkau Bersembahyang siswa sangat senang pada saat pembelajaran puisi tersebut.

Seluruh siswa memberikan tanggapan bahwa nilai-nilai religius dalam puisi Ketika Engkau Bersembahyang banyak menyumbang nilai-nilai yang bermanfaat dalam kehidupan sehari-hari sehingga siswa senang mempelajarinya, bahkan sebagaian besar siswa sudah pernah mempelajari nilai-nilai religius yang terkandung dalam puisi Ketika
Engkau Bersembahyang. Siswa juga memberikan tanggapan bahwa nilai-nilai religius sangat penting untuk dipelajari, karena krisi moral yang terjadi di negara kita sehingga siswa menganggap bahwa nilai-nilai religius sangat penting untuk dipelajari, selain itu juga sebagian besar siswa memberikan tanggapannya bahwa mereka tidak mengalami hambatan dalam pembelajaran menanggapi nilai religius pada puisi tersebut, dan sebagian besar siswa mengatakan bahwa bahasa yang digunakan dalam puisi tersebut dapat di pahami dengan mudah, bahkan sebagaian besar siswa menyatakan sudah pernah membaca puisi Ketika Engkau Bersembahyang karya Emha Ainun Nadjib, dan seluruh siswa memberikan tanggapan atau menyatakan bahwa puisi tersebut layak untuk dijadikan sebagai bahan pembelajaran sastra di SMA.

\section{SIMPULAN}

Sebagian besar siswa memperoleh nilai yang baik, dan hampir seluruh siswa memberikan tanggapan yang baik mengenai nilai-nilai religius yang terkandung dalam puisi tersebut, yang berhubungan dengan nilai religius keimanan, keistiqomahan, kesabaran, rasa bersyukur, rasa kasih sayang, teguh hati dan tidak berputus asa. Berdasarkan hasil tes dan tanggapan siswa hampir seluruhnya siswa atau sebagaian besar siswa memperoleh nilai yang baik. Serta, memberikan tanggapan-tanggapan yang baik pula.

Berdasarkan analisi data angket dapat diketahui seluruh siswa sangat menyukai atau senang mengikuti pembelajaran bahasa Indonesia. Berdasarkan hal tersebut, berarti siswa memiliki antusias yang tinggi untuk mengikuti pembelajaran bahasa Indonesia. Adapun, dinyatakan hampir seluruhnya siswa memberikan tanggapan bahwa mereka sangat menyukai pembelajaran sastra khususnya pembelajaran puisi. Berdasarkan data tersebut, dinyatakan seluruhnya siswa sangat menyukai puisi Ketika Engkau 
Bersembahyang atau siswa sangat senang ketika pembelajaran puisi tersebut.

Berdasarkan analisis angket, seluruh siswa memberikan tanggapan bahwa nilainilai religius dalam puisi Ketika Engkau Bersembahyang banyak menyumbang nilainilai yang bermanfaat dalam kehidupan sehari-hari, sebagian besar siswa sudah pernah mempelajari nilai-nilai religius yang terkandung dalam puisi Ketika Engkau Bersembahyang.

Seluruh siswa menyatakan bahwa nilainilai religius sangat penting untuk dipelajari. Senada dengan itu, sebagian besar siswa tidak mengalami hambatan dalam pembelajaran menanggapi nilai religius pada puisi, dan seluruh siswa menyatakan bahwa puisi tersebut layak untuk dijadikan sebagai bahan pembelajaran sastra di SMA.

Kemudian, sebagian besar siswa mengatakan bahwa bahasa yang digunakan dalam puisi tersebut dapat di pahami dengan mudah, dan adapun sebagaian besar siswa menyatakan sudah pernah membaca puisi Ketika Engkau Bersembahyang karya Emha Ainun Nadjib.

Beberapa saran yang perlu dikemukakan bagi guru dan siswa dalam pembelajaran sastra khususnya puisi. Siswa hendaknya sering membaca atau memahami makna yang terkandung dalam puisi agar siswa lebih memahami makna-makna yang ada dalam puisi yang dibacanya. Kemudian, siswa hendaknya lebih giat lagi ketika mengikuti pembelajaran sastra terutama puisi, agar ketika siswa membaca puisi mereka tidak berpikir membaca puisi itu hanya untuk mengisi waktu luang saja. Selain siswa, guru juga hendaknya memberikan instruksi kepada siswa dalam memahami pembelajran puisi sehingga siswa lebih giat dalam pembelajran sastra.

\section{DAFTAR PUSTAKA}

Gani, Erizal. 2014. Kiat Membaca Puisi. Bandung: Pustaka Reka Cipta.

Herimanto. 2010. Ilmu Sosial dan Budaya Dasar.Jakarta: Bumi Aksara.

Semi, Atar. 2013. Kritik Sastra. Bandung: Angkasa 